\title{
The National System of Education, $1831-2000$
}

\section{Tom Walsh}

\section{INTRODUCTION}

This chapter critically examines the establishment and development of the national system of education in Ireland between 1831 and 2000. The rationale for the establishment of the system is delineated at the outset. This is followed by an overview of the impact of wider contextual developments, including political, socio-economic, cultural and religious factors. The curricula developed and implemented in national schools during five distinct eras throughout the period are used as the armature around which the wider educational developments at primary level are structured. By focusing on what was taught, why it was taught and how it was taught, the chapter provides an insight into the evolving educational experiences of children in national schools in Ireland during the period. These curriculum eras are largely distinct by virtue of their context, the philosophy underpinning the curriculum, the content and methodologies advocated, the approach to teacher education and the concept of the child inherent in the curriculum. The five distinct periods are:

- The establishment of the national system [1831-1872]

- The era of Payment by Results [1872-1900]

- The Revised Programme of Instruction (1900) [1900-1922]

T. Walsh (四)

National University of Ireland, Maynooth, Ireland

(C) The Editor(s) (if applicable) and The Author(s) 2016

B. Walsh (ed.), Essays in the History of Irish Education,

DOI 10.1057/978-1-137-51482-0_2 
- The curricula developed following Independence [1922-1971]

- The Primary School Curriculum (1971) [1971-1999]

The chapter concludes by focusing on the key ideological changes underpinning the national system from its establishment in 1831 .

\section{The Origins of the National School System}

The decision to establish a national system of education in Ireland in 1831 arose in response to a number of political, social, economic and religious factors unique to the Irish context. ${ }^{1}$ It was primarily a political response to the difficulties of the British Empire in controlling its closest colony and was envisaged as a means to socialise the Irish populace and strengthen Ireland's link with the Empire. It was also a social and economic response to the widespread poverty and the quest for education evident in Ireland, with the intention that basic literacy and numeracy would improve the position of Ireland's citizens in future generations. It was also a product of the endeavours of the various religious denominations within Ireland to use schools to imbue the upcoming generations with their particular religious beliefs and ensure the survival of their faith.

The appetite of parents in Ireland for an education for their children continued after the repeal of the Penal Laws in the early 1800s. In the absence of a middle class to act as patrons for schools or of sufficient numbers of religious personnel to educate Catholic children, this demand was satisfied for the most part by establishing and supporting private feepaying Hedge Schools. ${ }^{2}$ Catholic teaching orders also established schools from the end of the eighteenth century, including the Presentation Sisters (1791), the Irish Christian Brothers (1802) and the Mercy Sisters (1828). As a result, Ireland had an extensive network of primary schools as evidenced by the 1824 census undertaken by the Commissioners of Irish Education, which established that approximately 560,000 children were attending 11,823 schools in that year. ${ }^{3}$ Only 1727 of the 11,823 schools in the country were under the control of state-funded societies, and the remaining 10,096 schools were largely Hedge Schools. ${ }^{4}$

The education provided in Hedge Schools was variable and the character of the teacher, often perceived to be morally dissolute and politically subversive, was outside the remit of either church or state. Both institutions wished to exercise control, for different reasons, over the teachers and learners. Owing to the colonial relationship with Ireland, the British 
authorities wished the education system to act as an agent of civilisation, socialisation, assimilation, politicisation and the reproduction of colonial values with a view to making Ireland more governable. ${ }^{5}$ From a religious point of view, schools and teachers could serve as conduits of the faith and instillers of religious values and loyalty. ${ }^{6}$ Such motivations led to state financing of Charter Schools and other organisations such as the Kildare Place Society (KPS) (1811), sometimes with the overt mission to proselytise and to provide alternatives to the unregulated Hedge Schools. However, the relationship between the Catholic and Protestant parties involved in the KPS deteriorated, particularly due to the Society's insistence upon the reading of scripture without comment and Catholic fears of proselytism, and the vast majority of Catholic children continued to attend Hedge Schools. ${ }^{8}$ Interestingly, the purpose of education was predominantly for social and moral reasons as opposed to providing a basic education in literacy and numeracy.

The Fourteenth Report from the Commissioners of the Board of Education in Ireland (1812) and two reports of the Commissioners of Irish Education Inquiry in 1825 and 1826 were instrumental in framing a system of education in Ireland. The 1812 report made a series of recommendations for the establishment of a National Board to administer a non-denominational system of education, to establish teacher training institutions and to approve textbooks. ${ }^{9}$ The first report of the Commission of Irish Education Inquiry (1824-1827) criticised the KPS for failing to meet its objective of providing education to all children without religious interference and recommended that no further grants be given to the Society. The report concluded with the recommendation that a national system overseen by a board of education be established where Catholic and Protestant children would be educated together. ${ }^{10}$

\section{The Stanley Letter (1831)}

The framework for the national system of education was outlined in a letter from the Chief Secretary, Lord Stanley, to the Duke of Leinster, Augustus Fitzgerald, in October 1831. The newly established model was, in many ways, similar to the existing system while its objective was

to afford combined [original emphasis] literary and moral, and separate [original emphasis] religious instruction, to children of all persuasions, as far as possible, in the same school, upon the fundamental principle, that no 
attempt shall be made to interfere with the peculiar religious tenets of any description of Christian pupils. ${ }^{11}$

The core functions of the National Board that presided over the national system, as stated in the Stanley Letter, comprised of men of high moral standing and of different religious denominations, were to 'exercise a complete control over the various schools which may be erected under its auspices.' 12 This included the management of school buildings, curricula, textbooks, school grants, teacher training and the inspection system. This concern with complete control over the curriculum and teachers by the Board was symptomatic of its desire for cultural, political and social assimilation and to ensure that a central policy prevailed in schools. ${ }^{13}$ At a local level, the multiplicity of agencies, denominational leaders, educational societies and political groups that had been involved in the management of schools prior to 1831 was largely replaced by single denominational school managers. The power of individual managers rested largely in the recruitment and dismissal of teachers and in monitoring the work of the school and in supporting school ethos.

The National Board encouraged joint applications from religious denominations to establish or to bring existing schools under its auspices. State support for education prior to 1831 had been largely for proselytising purposes, and there was a deep mistrust of state intervention and a history of hostility between the various denominations. ${ }^{14}$ However, the churches etched away at the mixed denominational principle of the national system, and in reality, most schools were vested in diocesan trustees, had the local Bishop as their patron, were clerically managed and the managers, teachers and pupils were of the same faith. As the majority of the Protestant schools remained outside the national system and within the Church Education Society ${ }^{15}$ from 1839 to 1869 , this meant that the majority of schools were managed by and vested in the Catholic Church. By 1850, less than $4 \%$ of National Schools were under conjoint clerical and lay management. ${ }^{16} \mathrm{By}$ 1900 , the system had become denominational in practice with nearly $65 \%$ of schools denominationally homogeneous while $80 \%$ had clerical managers. ${ }^{17}$ At the Catholic General Synod in Maynooth in 1900, the hierarchy indicated its overall satisfaction with the system being 'as denominational as we could desire. In most of its schools there is no mixed education whatsoever.' ${ }^{18}$

As the system was more for socialisation and assimilation purposes, an equal emphasis was placed on the participation of boys and girls. By 1900, 
the system comprised a network of 8684 schools, catering for the education of 770,622 pupils, in every village and townland in Ireland. ${ }^{19}$ There was a significant decline in the rates of illiteracy from the inception of the national system in 1831 to the end of the century, reducing from $52.7 \%$ of the population over age five who could not read or write in 1841 to $18.4 \%$ by $1891 .{ }^{20}$

It is important to consider the wider social context as it was in this environment that certain decisions and directions were taken by the education system. Religious, political, social, economic and cultural contextual factors from 1831 to 2000 are treated in the next section.

\section{Factors Impacting upon the Development of THE SCHOOL System}

\section{Religious}

The Catholic Church positioned itself as integral to the new national system, strategically acting as a partner to the state in the establishment of schools. This proved to be a symbiotic alliance considering the concerns of both the Catholic Church and the colonial power to focus on the social and moral wellbeing of pupils and the instilling of civility through the school system..$^{21}$ The timing coincided with the gradual rise of the power and prominence of the Catholic Church in Ireland as the leader of a loyal laity, achieving Catholic Emancipation in 1829, and offering 'a substitute badge of ethnicity to distinguish them [the Irish people] from the colonial establishment'. ${ }^{22}$ The growth and prominence of the Catholic Church was mirrored by the demise of the Church of Ireland and the relationship between these churches was generally characterised by distrust, suspicion and hostility. Arguably, the increasing influence of the Catholic Church in Ireland in the nineteenth century was largely owing to its central involvement in an extensive network of schools and its overt success in shaping the education system to its desired structure. ${ }^{23}$ While represented at a national level on the National Board and other such structures, its real power and influence rested in the managerial system, whereby its clerics controlled the recruitment and management of teachers in the majority of schools in Ireland, and it began to regulate the lives of pupils and their parents through schooling.

The position carved out in the nineteenth century of a 'parochially organised, denominationally segregated and clerically managed ${ }^{24}$ system was strengthened and defended from local and lay involvement in the 
early twentieth century. ${ }^{25}$ The oftentimes uneasy relationship between the Catholic Church and the British authorities prior to Independence in 1921 was replaced by a more symbiotic and natural union of Church and state from the $1920 \mathrm{~s} .{ }^{26}$ While playing a central role in education prior to Independence, the Central Association of Catholic Clerical School Managers outlined its expectation for complete control over education in the Free State in 1921:

And, in view of pending changes in Irish education, we wish to assert that the only satisfactory system of education for Catholics is one wherein Catholic children are taught in Catholic schools by Catholic teachers under Catholic control. ${ }^{27}$

The power of the Catholic Church grew further after Independence in 1921, becoming an omnipresent and triumphant force in Irish society as it celebrated the centenary of Catholic Emancipation in 1929 and hosted the Eucharistic Congress in 1932. The decreasing Protestant population is evident in the reduction in their number enrolled in primary schools, falling from $5 \%$ in 1924 to $2.5 \%$ in $1965 .{ }^{28}$ The state acknowledged the pivotal position of the Catholic Church and accepted its authority in matters such as education, describing the system as being semi-state, with power shared between the state and the managers. ${ }^{29}$ The former's subsidiary role in relation to education was enshrined in the Irish constitution, Bunreacht na hÉireann (1937). ${ }^{30}$ Moreover, both church and state maintained a binary control over education until towards the end of the twentieth century when more democratic structures were introduced to allow for a greater partnership approach to the development of education policy. Growing ecumenism and a greater role for parents and the laity in education introduced by the reforms of Vatican $\mathrm{II}^{31}$ coincided with a decrease in vocations in Ireland. Furthermore, parents (through the National Parents' Council Primary established in 1985) and teacher unions began to occupy a more pivotal and powerful role within the education system. ${ }^{32}$ While Boards of Management were introduced in 1975 to replace largely individual clerical managers, they did not lead to an absolute release of power as the chairperson of boards was generally clerical and were appointed by the patron. ${ }^{33}$ While the physical presence of religious teachers in schools had all but disappeared by 2000 , the Catholic Church through its ownership, trusteeship and management of schools, and its considerable consultative powers, remained a dominant force in Irish education. ${ }^{34}$ 


\section{Political}

From a political perspective, the establishment of a national education system by a colonial power placed the focus of education on social reproduction, colonial assimilation and increased allegiance to the British Empire. For the first 90 years of the system, decisions relating to education were determined at Westminster and were greatly influenced by developments in England and the wider Empire. These decisions were not always appropriate for the distinct Irish context and many policy initiatives, including curricula, did not gain traction as a result. Following Independence, the education system became the means of achieving a range of national aspirations, most notably the revival of the Irish language and the building of Irish nationhood. The dominance of this underlying philosophy within the education system for close to 50 years following Independence impacted on the content and methodologies used, on the selection and recruitment of teachers and, consequently, on the learning experiences of and outcomes for pupils. The state, through the Department of Education, drew up the regulations that governed education and retained tight control over the curriculum.

There have been few ideological differences between the main political parties since Independence and most evolved their thinking simultaneously on the role of the state in education. ${ }^{35}$ Interestingly, international influences on education came to the fore again from the 1960s owing to Ireland's engagement with institutions such as the Organisation for Economic Co-operation and Development (OECD) and the European Economic Community (EEC). This changed the conceptualisation of education as having solely moral and social purposes to include a more human capital and economic dimension from the 1960s. A process of social partnership and consultation between the government, employers and trade unions underpinned industrial relations and education policy development from the 1980s. ${ }^{36}$

\section{Social}

It is evident that significant value was placed on education in Ireland, particularly when Irish society was at its most oppressed and weakened in the early nineteenth century. Many parents, most of whom had little means, paid for their children to attend Hedge Schools and other private schools prior to 1831. The formative influence of education was also understood 
by both the British authorities and the churches, albeit for different purposes, with each assuming a direct involvement in its development and delivery. ${ }^{37}$ However, the societal circumstances that whetted the appetite for education were also those that prevented many children from participating fully in education, owing to limitations of finance, the necessity for manual labour on subsistence farms and the poor living conditions in towns and cities. ${ }^{38}$ Doyle asserts that the 1800s 'led to seismic upheavals in Irish society' ${ }^{39}$ ranging from Act of Union in 1801 to the destructive effects of the Great Famine of the 1840s and the move towards militant nationalism at the turn of the twentieth century. Following Independence, the people of the Irish Free State were predominantly rurally based, Catholic and socially conservative. ${ }^{40}$ Church and state were increasingly concerned in relation to the alleged decline in moral standards from the 1920s, especially sexual morality, which led to a paternal and protectionist ethos in Ireland. While, internationally, there were moves to improve and widen access to social services after World War II, the same thrust for reform was not as immediate in Ireland. ${ }^{41}$ While dramatic social changes in the 1960s served to break the insularity and isolationist stance of Irish society, ${ }^{42}$ Ireland remained a largely conservative and Catholic society towards the end of the twentieth century. ${ }^{43}$

\section{Economic}

From an economic perspective, the rapid growth of the national system placed great strain on the available financial resources from 1831 . Throughout the period of rule by England, decisions around the financing of Irish education were made for a variety of reasons, oftentimes political, and were influenced by other developments and issues within the wider Empire. The creation of a national system by the colonial power catalysed a withdrawal of local monetary support for education leading to the necessity for higher funding for education in Ireland than in England due to the absence of local rates and support. ${ }^{44}$ The fledgling Irish Free State had limited resources available to it for decades after its establishment and economic policy did not prioritise high levels of social spending. ${ }^{45}$ The funding of Irish education was often supplemented through voluntary parental support and institutional church support. Competing societal demands and changing economic fortunes seemed always to mean that the resources available for education in Ireland were insufficient to meet the needs of the system. A changing conceptualisation of education 
as an economic necessity as opposed to a social expense for 'moral, intellectual, and religious objectives" 46 became evident from the 1960s. This was heralded by seminal policy documents such as Economic Development in $1958^{47}$ and the Investment in Education report in $1965,{ }^{48}$ leading to increased economic provision for education. As Minister O'Malley asserted in 1967, Ireland 'as a small and poor country cannot afford not to spend more on education than a richer one. ${ }^{39}$ Increased participation at postprimary and tertiary levels from the 1960s placed competing demands on the education budget.

\section{Cultural}

The national system actively disregarded any distinct elements of Irish culture within the school system, most notably the Irish language, until the early 1900s. O'Donoghue asserts that this policy also operated in other British colonies, including Scotland, Wales, Cyprus and Malta. ${ }^{50}$ Generally, however, and in particular following the Famine, this neglect of Irish language and culture met with the tacit acceptance and approval of the dominant parties in the education system, including the Catholic Church, political activists and parents. ${ }^{51}$ Throughout the nineteenth century, the language became increasingly synonymous with poverty, disaffection, defeat and ignorance, 'the badge of a scattered minority in a number of restricted, remote and impoverished regions in the western fringes of Ireland. ${ }^{52}$ It was only towards the end of the nineteenth century that there were moves to revive the Irish language and culture through organisations such as the Society for the Preservation of the Irish Language (1876), the Gaelic Athletic Association (1884) and the Gaelic League (1893). ${ }^{53}$

The Gaelic League repeatedly highlighted what it characterised as the non-Irish character of education in the national schools and was successful in campaigning for the introduction of the Bilingual Programme in 1904. The cultural revival movement, spearheaded by the aforementioned organisations, peaked around the 1920s and had widespread support from many prominent politicians and professionals in positions of power. When the pendulum swung following 1921 to place an inordinate emphasis on Irish language and culture within the school system, the majority of the population displayed a tacit, positive disposition yet there were few practical manifestations of this support at a popular level outside the school system. Akenson asserts that there was a "cultural implosion'54 
in Ireland from the 1920s as the threat of omnipresent English language and culture threatened the policy ideal of a return to a Gaelic Ireland that was being propagated through the education system. Relaxation of this insularity, coupled with a more balanced appreciation of Irish and international cultures and diversity generally, were more evident from the 1960s.

It was within this broader societal context that the curricula between 1831 and 2000 was developed and implemented. Five distinct eras in the evolution and development of the national system are detailed in this chapter.

\section{The Establishment of the National System, 1831-1872}

The curriculum implemented in national schools following 1831 provided for combined moral and literary education and separate religious instruction. A great emphasis was placed on instruction in literary and mathematical subjects (see Appendix 1). As many of the schools in the national system had their origins in the KPS and Hedge Schools, many pedagogical practices from previous traditions were transported into the new system. For example, many teachers instructed pupils individually rather than as a class, and this practice was gradually replaced by the simultaneous model of instruction from the 1840s. The Commissioners of National Education produced and approved textbooks for use in schools and these were largely factual and moralistic in nature, urging acceptance of the political and social status quo. The five Reading Books sanctioned by the National Board became a core element of the work of the school, yet the majority of pupils failed to proceed beyond level three prior to $1870 .^{55}$ Instruction was through the medium of English and there was little reference to distinct aspects of Irish culture, language or tradition. Attendance rates were very poor. As late as 1870 , only $36 \%$ of the school-going cohort attended school regularly largely due to the difficult socio-economic circumstances of the country. ${ }^{56}$

Inspection was integral to the national system from 1831 and the cadre of inspectors grew exponentially throughout the nineteenth century. ${ }^{57}$ Inspectors were seen as the key agents in ensuring that the rules and regulations of the National Board were implemented at a local level by managers and schools. Initially, inspectors were men of high educational attainment and social standing and only gradually from the midnineteenth century were some recruited from the teaching profession. The role of the inspector was to communicate to the patron/manager as well 
as the Commissioners 'as to the proficiency of the pupils, and the discipline, management, and methods of instruction pursued in the School. ${ }^{58}$

\section{Teacher Education, 1831-1872}

Central to the Stanley Letter was the provision of training facilities for teachers. This was considered important and necessary by both church and state to remove the unevenness of teacher competence and character that previously prevailed. However, the nature and organisation of teacher training remained a contentious issue throughout most of the nineteenth century. The National Board considered teachers to be significant agents of social control and political stability ${ }^{59}$ and were to be "trained to good habits; identified in interest with the State, and therefore anxious to promote a spirit of obedience to lawful authority. ${ }^{60}$ A national training college operated in Marlborough Street, Dublin from 1838. Between 1843 and 1867, a network of 26 interdenominational District Model Schools was established 'to promote the united education of Protestants and Roman Catholics in Common Schools; to exhibit the best examples of National Schools; and to give preparatory training to young teachers. ${ }^{61}$ The mixed gender and denominational status of the District Model Schools was a major source of concern for the Catholic Church as it exercised no control over their management or activities and an outright ban on attendance for Catholics was instituted by the Catholic hierarchy between 1863 and 1924. The consequence of this stance was that by the 1870 s, only $34 \%$ of teachers were formally trained, the proportion of Catholic teachers being lower at $27 \% .{ }^{62}$ The national system established elaborate structures, procedures and rules to tightly manage the educational and moral conduct of teachers employed, including the managerial system, the inspection system and the 12 practical rules for teachers (see Appendix 2). ${ }^{63}$ With the establishment of the Irish National Teachers' Association (later Organisation) (INTO) in 1868, the rights of teachers, in terms of pay and conditions, became more contested.

\section{The Era of Payment by Results}

A Royal Commission of Inquiry into Primary Education, the Powis Commission, was established in 1870 to inquire into the education system in Ireland. Among its findings, it reported limited educational progress for many pupils in the education system based on the Reading Book level attained and general educational proficiency as reported by inspectors coupled with poor material and resource conditions in many 
schools. Among the 129 recommendations, it proposed the introduction of a system of Payment by Results and denominational teacher training facilities. A similar system of Payment by Results had been introduced in England, and it was seen as a measure to ensure greater efficiency and accountability within the system:

That to secure a better return for the outlay and labour of the National system, each Teacher, besides a fixed class-salary, should receive an addition according to the number of children whom the Inspector, after individual examination, can pass as having made satisfactory progress during that year. ${ }^{64}$

This curriculum revision affected not only the nature of instruction, which became more mechanical and exam-focused, but also the range of subjects studied. It resulted in a major concentration on English reading, writing, and spelling, as well as Arithmetic. While two additional subjects from a list of 21 could be studied, there was little uptake of these in the years following 1870. Precise programmes in each subject were developed and pupils were examined annually by inspectors with a focus on mechanical proficiency. A minimum of 100 attendances was necessary to present for examinations and higher fees were paid for older pupils. This led to greater progression for pupils in schools, reduced illiteracy rates, improved the attendance of pupils to $62 \%$ by $1900^{65}$ and motivated some teachers to improve the quality of their work. However, it reduced the breadth of the curriculum to a narrow focus on certain subjects and resulted in a more didactic approach to teaching to achieve mechanical accuracy. As stated by Hyland and Milne:

The system of payment by results fostered a narrow approach to the curriculum, both in terms of content and methodology. It encouraged rotelearning and made no allowance for differences between pupils or between schools. ${ }^{66}$

No doubt, this resulted in a greater neglect of younger pupils in schools, as higher results fees were paid for older pupils, and strained relations between inspectors and teachers.

\section{Teacher Education, 1872-1900}

The increasing power, authority and coherence of the Catholic Church in the 1800s resulted in its securing denominational training colleges in 
1883. The two-year training programme was intensive in nature and prepared teachers to practise a structured and didactic pedagogy in classrooms, largely influenced by Joyce's A Handbook of School Management and Methods of Teaching. ${ }^{67}$ By 1900, there were six denominational training colleges receiving state funding in addition to the mixed denominational central training college in Marlborough Street. This was a major strategic victory for the Catholic Church, which now controlled entry to the nature and content of the training and the recruitment and dismissal of teachers in Catholic-managed schools. The number of untrained teachers had reduced to $55.2 \%$ by $1896 .^{68}$

\section{The period of the Revised Programme of Instruction (1900) [1900-1922]} The design of the Revised Programme of Instruction (1900) was based on a comprehensive national and international review of educational provision at the time by the Commission on Manual and Practical Instruction (1898). ${ }^{69}$ It was influenced by international developments in the conceptualisation of the child informed by the Romantic Movement and the move to introduce subjects of a manual and practical nature in school curricula using more heuristic methodologies.

Dr. Starkie, the Resident Commissioner (1900-1922), played a central role in developing the ambitious Revised Programme of Instruction (1900). The Programme introduced many new manual and practical subjects (see Appendix 1), changed the focus on existing subjects, altered the methodologies employed to ensure an emphasis on activity and discovery learning and allowed for local adaptation of content. Particular emphasis was placed on the education of children in the infant classes, where there was to be a focus on enjoyment and hands-on activity. Such a major change in underlying philosophy and content required systematic planning and resourcing for it to become institutionalised at a school level. However, Dr. Starkie neglected to take on board the concerns expressed by inspectors, managers and teachers about the feasibility of implementing such an ambitious programme in the school context of the time and its ambition was to be its greatest weakness in the educational context of the early twentieth century. This undermined an otherwise conceptually and pedagogically well designed programme and despite revisions in 1904, the envisaged programme never achieved traction in Irish schools. As stated by Hyland: 
It was a theoretically impressive curriculum but among its weaknesses were a lack of consultation with teachers and inspectors at the drafting stage and failure to take account of the constraints, both physical and human, within the national school system of the period. ${ }^{70}$

Inspector reports following $1900^{71}$ and an evaluation of the system in 1903 by an English inspector, Mr. Dale, ${ }^{72}$ report instances of implementation of the programme and a general improvement in learning atmospheres in schools, a wider variety of subjects being studied and improved methodologies. However, the overall vision, methodologies and content of the Revised Programme was realised in few schools. ${ }^{73}$ Interestingly, Dale noted the greatest innovation in newly introduced subjects and less transformation in the content and methodologies of well-established subjects or those needing additional equipment and resources. The main barriers to its adoption rested with insufficient teacher training, inadequate funding, the poor materials and resources in schools, low rates of pupil attendance and the lack of popular support for the programme. This led to revisions to the programme in $1904 .{ }^{74}$ Attendance rates continued to improve, somewhat assisted by the passing of school attendance legislation in 1892 , and rested at $65.7 \%$ in $1904 .^{75}$

The Irish language was not used as a medium of instruction or as a subject to be taught following the establishment of the national system in 1831. Despite campaigns for its recognition as a subject, particularly in Gaeltacht (Irish speaking) regions, it was 1878 before it was recognised as an additional subject that could be taught outside school hours for fees. In 1904, a Bilingual Programme was introduced that, under certain conditions and circumstances, allowed for subjects to be taught bilingually using the Irish and English language. ${ }^{76}$ Approximately $3 \%$ of schools participated in the Bilingual Programme by 1920 while approximately $20 \%$ offered Irish as an additional subject. ${ }^{77}$

\section{Teacher Education, 1900-1922}

The programme in teacher training colleges was revised in the late $1890 \mathrm{~s}$ in line with the Revised Programme (1900) and further manual and practical subjects were added. Dr Starkie was critical of the quality of teacher training during the era where teachers had no opportunity 'of acquiring a liberal culture, and, what is still more important, a wide knowledge of human nature and of life'. ${ }^{78}$ While he did not succeed in introducing a 
university-based education for teachers, he removed some of the social restrictions on teachers (such as the right to attend political meetings from 1906 and the need for a quarterly 'character query' from the manager from 1911) and extended the range of courses available to them. ${ }^{79}$ A number of Organisers were also appointed in various subjects to support teachers in introducing the new subjects in the 1900 curriculum. ${ }^{80}$ Great strides were made in the period after 1900 to ensure all teachers attended training colleges, so that by $1919,80 \%$ of teachers were formally trained. ${ }^{81}$

\section{The Curricula Developed Following Independence, 1922-1971}

Following the advent of independence in 1921, the first National Programme Conference $(1922)^{82}$ and Second National Programme Conference $(1926)^{83}$ established curriculum policy for national schools that largely informed practice until 1971. Criticisms of the pre-Independence curriculum included its broad nature and its lack of reference to Irish language and culture. Developed amid the patriotic fervour of the fledgling Free State, it was inevitable that the programmes became imbued with certain distinctive aspects of Irish language, culture and tradition. A keynote of nationalism in the European context was that a country with its own distinct language and culture should constitute a state. ${ }^{84}$ The revival of the Irish language became synonymous with the task of nation building in a post-colonial context, a view that gained momentum in the 1930s as articulated by Taoiseach de Valera,

we cannot fulfil our destiny as a nation unless we are an Irish nation-and we can only be truly that if we are an Irish-speaking nation. ${ }^{85}$

A consequence of this perspective was to interlink issues of patriotism, nationalism and the Irish language revival within the school system. The extent of this inculcation was accentuated owing to the positions held by key Irish language enthusiasts at a political and societal level in the 1920s. ${ }^{86}$ The Irish and English languages were contrasted against one another, with the former representing an idealised, pure past and the latter a reminder of colonial legacy. ${ }^{87}$ As stated by the government in 1925 ,

it is the intention of the new government to work with all its might for the strengthening of the national fibre by giving the language, history, music and tradition of Ireland their natural place in the life of Irish schools. ${ }^{88}$ 
From 1922, the number of compulsory subjects was reduced (see Appendix 1). The main change was the introduction of Irish as a compulsory subject in schools to be taught for one hour per day, and further advising its integration with other subjects. Moreover, the 'work in the Infant standard [classes] is to be entirely in Irish. ${ }^{89}$ This was in a context where English was the vernacular of $90 \%$ of the pupils, where only $5 \%$ of schools were operating the Bilingual Programme and where the majority of teachers had no certified qualification in the language (see Table 2.1)..$^{90}$ The obligatory subjects remained largely the same after the Second National Programme Conference in 1926 (see Appendix 1). However, it also allowed for some teaching of English in the infant classes before 10:30 a.m. and after 2:00 p.m. Moreover, a Higher Course and Lower Course were introduced in Irish in 1926 to be undertaken based on the linguistic competence of the teachers and pupils. The programmes introduced in the 1920s allowed for local adaptation by managers and teachers, subject to Inspectorate approval, but this facility was rarely availed of. Moreover, the dominant emphasis placed on the language revival reduced the time afforded to other subjects in the curriculum, most notably English. Indeed, the requirement to use Irish as the medium of instruction in the infant classes remained in place until 1960..$^{11}$

Two further revisions of the curriculum were introduced in 1934 and 1948. In 1934, the Minister reduced the requirements in a number of subjects to allow for a greater focus on the Irish language, requiring all schools to adopt the Higher Course in Irish and the Lower Course in

Table 2.1 Qualifications in Irish of all teachers serving in National Schools, $1924-1960$

\begin{tabular}{lllll}
\hline School year & $\begin{array}{l}\text { No Certificate } \\
\text { in Irish }\end{array}$ & $\begin{array}{l}\text { Ordinary } \\
\text { certificate }\end{array}$ & $\begin{array}{l}\text { Bilingual } \\
\text { certificate }\end{array}$ & $\begin{array}{l}\text { Ard } \\
\text { Teastas }\end{array}$ \\
\hline 1924 & 59.2 & 20.7 & 17.6 & 2.5 \\
$1930-1931$ & 27.2 & 33.4 & 33.4 & 6 \\
$1940-1941$ & 11.1 & 24.5 & 57.6 & 6.8 \\
$1949-1950$ & 8.3 & 16.9 & 68.6 & 6.2 \\
$1960-1961$ & 4 & 6.6 & 85.1 & 4.3 \\
\hline
\end{tabular}

Source: Deputy McGilligan (1925). Dáil Debates, June 2, 1925, Volume 12, Column 2; Department of Education (1931). Report of the Department of Education 1929-1930, Dublin: The Stationery Office, p. 139...(1941). Report of the Department of Education 1939-44, p. 9...(1951). Report of the Department of Education 1949-1950, p. 107 An Roinn Oideachais (1961). Tuarascáil 1959-1960. Baile Átha Cliath: Oifig an tSoláthair, p. 89 
English. ${ }^{92}$ The Revised Programme for Infants $(1948)^{93}$ and the accompanying Notes for Teachers in 1951 returned, in theory at least, to the principles and ideology underpinning the earlier programme in 1900, placing an emphasis on the holistic development of the child and on meeting his/ her needs through activity and discovery learning:

The purpose of the infant school is to provide for young children the environment, opportunities and activities most favourable to their full development. Infant teaching, if it is to be successful, must be based on the young child's instinctive urge to play, to talk, to imitate, to manipulate materials, to make and do things. ${ }^{94}$

Despite evidence that the revival of the language was not succeeding and concerns in relation to the wider education of pupils, little reform of the curriculum was attempted until the late 1960s. Progress on the revival of the Irish language through the education system was hampered from the outset by wider public apathy for the language, the lack of parallel strategies outside the school system to promote the language and by the lack of competence or qualifications on behalf of most teachers either to teach the language or use it as a medium of instruction. ${ }^{95}$ Issues with standardisation of the language in terms of grammar, spellings and typeface until the 1940s further impeded its revival prospects, with little guidance for textbook publishers or teachers.

The Primary Certificate Examination was introduced in 1943 on a compulsory basis and was designed to testify to the completion of sixth class standard..$^{96}$ Its focus was on written examinations in Irish, English and Arithmetic only and had the effect of further narrowing the focus of the curriculum taught in schools until its abolition in 1967. Evaluations of the implementation of the curriculum during this period evidence poor progress in relation to the Irish language and an increasingly narrow curriculum experience for pupils. ${ }^{97}$ The Report of the Council of Education in 1954 largely reinforced the status quo in primary education. ${ }^{98}$

\section{Teacher Education, 1922-1971}

A number of revisions to the training of teachers were undertaken between 1922 and 1971, largely focused on improving their competence in the Irish language. Teacher training courses were also revised and an increasingly Gaelic atmosphere was achieved in these institutions, which 
generally remained closed off from wider tertiary education until the 1960s. ${ }^{99}$ A central element of this focus was the establishment of seven preparatory colleges 'for those clever boys and girls of the Irish-speaking districts who desire to become teachers'. ${ }^{100}$ These colleges operated until 1960 (the Protestant college operated until 1995) and provided a postprimary education to students who had committed to become teachers. By 1936, close to $50 \%$ of candidates entering the training colleges had come through the preparatory system, with the remainder coming from the pupil-teacher scheme ${ }^{101}(16.6 \%)$, the Easter Examinations ${ }^{102}(21.5 \%)$ and university graduates (15\%). ${ }^{103}$ The Report of the Council of Education estimated that $15 \%$ of serving teachers in schools had been educated in the preparatory colleges by $1950 .{ }^{104}$ While the preparatory scheme had a positive effect on competency in Irish within the system, it narrowed the potential pool of entrants to the profession during the period. By 1971, approximately $6 \%$ of the teaching force remained untrained. ${ }^{105}$

As demonstrated in Table 2.1, teacher qualifications in Irish improved from the 1920s. However, the rate of development did not provide for the revolution that was needed in terms of teaching the Irish language or using it as a medium of instruction.

Moreover, teacher competence in the Irish language became a requirement for the payment of increments and for favourable inspector ratings from the 1930s. ${ }^{106}$ Linking competence in the Irish language to the payment of increments and teacher ratings did little to enamour teachers to the Irish language. The revival within the schools peaked in the early 1940s, from when there was a continuous decline in the number of schools using Irish as a medium of instruction from 623 (12\%) in 1940 to $251(6 \%)$ in $1970 .{ }^{107}$ Moreover, despite much endeavour, the number of Irish speakers in Gaeltacht regions declined from 244,904 speakers in 1926 to 164,229 speakers by $1961 .^{108}$

\section{The Primary School Curriculum, 1971-1999}

There were increasing concerns with the curriculum by the 1960s as Ireland opened up to wider international influences and began to examine the relevance of the education system for economic advancement. ${ }^{109}$ The seminal Investment in Education report in 1965 provided a wealth of statistical data enumerating many of the challenges in the system and provided evidence of the need for reform. The main concerns related to the dominant position of the Irish language in the curriculum, the narrow range of subjects offered, the inequitable distribution of resources 
across schools and the irrelevance of the curriculum for the future lives and occupations of students. ${ }^{110}$ Reform of the primary school curriculum was also necessary in light of the increased expansion and universal provision of post-primary schooling from the late 1960s, which almost doubled the number of post-primary students between 1960 and 1970. From the 1960s, there was increasing provision for children with special educational needs ${ }^{111}$ and affected by educational disadvantage. ${ }^{112}$ Despite an increased diversification of Irish society, the vast majority of schools continued to be denominational, with a gradual growth in the number of Gaelscoileanna ${ }^{113}$ and multidenominational schools, ${ }^{114}$ particularly from the 1990s.

Planning for the new curriculum was co-ordinated by the Inspectorate between 1966 and 1971, during which time drafts were circulated for consultation to a limited number of stakeholders and a pilot project was undertaken to trial the new curriculum in approximately $20 \%$ of schools. ${ }^{115}$ However, limited action was taken to address the concerns arising from the consultative or piloting processes. The New Curriculum published in 1971 had two overarching aims which continue to underpin primary education in Ireland in the twenty-first century:

- To enable the child to live a full life as a child;

- To equip him (sic) to avail himself ( sic) of further education so that he (sic) may go on to live a full and useful life as an adult in society. ${ }^{116}$

The bilingual handbooks outlined the aim, objectives, syllabus content and opportunities for integration for each of the compulsory subjects, namely Irish, English, Mathematics, Art and Craft, Social and Environmental Studies (History, Geography, Nature Studies, Civics), Music and Physical Education. Religious Education was also compulsory, but no curriculum was laid out by the Department for this subject. Not only did the content of the curriculum change but the nature of its delivery was also altered by the implicit principles of the curriculum, including a focus on individualised instruction, the full and harmonious development of the child, the use of activity and discovery methods, the integrated nature of the curriculum and the basing of instruction on the child's environment. This provided for a radical shift in ideology, content and methods from its predecessor, reverting to a child-centred philosophy and a broad programme of instruction. In Irish, a graded programme using audiovisual aids (Buntús Gaeilge) was introduced to deliver the curriculum from the late 1960s. ${ }^{117}$ The leadership role of the principal in 
schools was emphasised and the role of teachers was to facilitate pupils' learning.

Once again, the philosophy, content and methodologies proposed by the 1971 curriculum differed greatly from its predecessors in the 1920s. Despite the overwhelming endorsement of the aims and principles of the New Curriculum, it is clear that many of its provisions were not realised in practice between 1971 and 1999. As Sugrue stated, while teachers endorsed progressive ideology, 'when data on actual practice are isolated from these studies teachers seem to endorse a child-centred rhetoric while practising a more formal pedagogical style.'118 Evidence on curriculum implementation strongly suggests that many pupils continued to be educated in a narrow range of subjects in a formal way which did not embrace the curriculum principles or approaches. ${ }^{19}$ Some of this related to teacher competence and confidence in the new subjects, lack of resources, the predominance of large class sizes and the pressures of time to implement a wider curriculum. It is also arguable that teacher conservatism and reluctance to change engrained and encultured practices also impacted negatively on enacting the curriculum in practice. As stated by the OECD in 1991

Despite the vision and thoroughness of the 1971 primary schools curriculum proposals and the many practical innovations since carried through by dedicated teachers, the evidence suggests that emphasis is still largely on a didactic approach and often, in later primary years, in a relatively narrow range of subject matter. ${ }^{120}$

\section{Teacher Education, 1971-1999}

There were major developments in teacher education in the 1970s and three-year degree courses were instituted in newly constituted Colleges of Education from 1974. The teaching profession continued to attract applicants from the top quartile of entrants to third-level education. ${ }^{121}$ Degree status facilitated teachers in undertaking further postgraduate studies and the Educational Studies Association of Ireland (founded in 1976) provided an active forum for educational discussion. However, research on the education system was limited and piecemeal throughout the era and a number of commentators called for increased funding and focus on research. ${ }^{122}$ A network of Teachers' Centres was established to act as a focal point for teachers to meet, to provide lectures and seminars, 
to deliver in-service courses and induction programmes and to provide and display resources and materials. ${ }^{123}$ However, systematic provision for in-service education was not achieved prior to 2000, and this impacted negatively on the ability of teachers to develop professionally or respond to evolving priorities and practices within the system.

\section{Moving Towards the Primary School Curriculum (1999)}

Two major reviews of the education system were published in 1990: the Report of the Primary Education Review Body ${ }^{124}$ and the Review Body on the Primary Curriculum. ${ }^{125}$ These reports, among other factors, catalysed a decade of educational development and reform in the 1990s. Work at a curricular level was also heavily influenced by wider policy developments, such as the drafting of a Green Paper on Education (1992), ${ }^{126}$ the National Education Convention (1993), ${ }^{127}$ the White Paper on Education (1995 $)^{128}$ and legislation to establish a Teaching Council in 2001. ${ }^{129}$ Following protracted negotiations, the Education Act $1998^{130}$ was published, and this provided the first comprehensive legislative framework for the education system. Individually and collectively, the policy developments in the 1990s reformed and articulated many of the structures and principles underpinning Irish education and represented the most intense period of reform since the establishment of the national system in 1831 .

From a curricular perspective, the National Council for Curriculum and Assessment was established in 1987 operating a partnership and participatory approach to curriculum development. The revision of the curriculum in the 1990s, culminating in the Primary School Curriculum (1999), ${ }^{131}$ was undertaken by a range of committees representative of the education partners. For the first time in curriculum history in Ireland, the 1999 curriculum built on the philosophy and content of its predecessor representing a less dramatic swing of the pendulum for teachers.

\section{Conclusion: The Changing Philosophy and Ideology of the National System}

In the close to two centuries since the establishment of the national system, it is evident that it has served many purposes and been motivated by many factors that reflected the wider societal context. These 
changing purposes have had a direct impact on the concept of the child inherent within the system and on his/her educational experience. ${ }^{132}$ The initial motivation for establishing the national system of education in Ireland was a social and moral impetus by a colonial power that wished to imbue Irish children with colonial values. It also wished to exercise control over what was taught in schools and who had the right to teach, a motivation shared by the Catholic Church. Therefore, while the curriculum introduced in 1831 contained aspects of literacy and numeracy at its core, its central aim was to imbue in children a sense of belonging to the Empire and to instil a sense of loyalty to colonial values and structures. For this reason, many of the school books approved or produced by the National Board contained strong moral overtones and any distinct reference to Irish culture or history was avoided.

In line with a greater focus in England on efficiency and accountability in public services from the 1850s, the era of Payment by Results from 1872 heralded a greater emphasis on educational outcomes by individual children, particularly in relation to literacy and numeracy. This had the effect of catalysing the reduction in illiteracy rates in Ireland between 1870 and 1900 and further regulated the lives of pupils and their parents by insisting on a minimum number of attendances. From 1900, the philosophy underpinning the curriculum changed dramatically and a greater emphasis was placed on the interest, needs, agency and curiosity of the child to inform his/her learning. This approach was influenced by the wider New Education Movement in Europe. ${ }^{133}$

The changes introduced in the 1920s were radical in terms of philosophy, content and approach. The national objective of reviving the Irish language and of building nationhood became a key priority for the new Free State government, and the school system was seen as a key tool in this endeavour. It is arguable that the pedagogical needs and interests of the child were usurped during this era by nationalistic and linguistic endeavours. Moreover, the dominant position of the Catholic Church in the ownership, management and control of the education system resulted in a strong moralising influence in Irish schools. From 1926, 
religion became an integral element and unifying force of the primary school curriculum, reiterated in the Rules for National Schools $(1965)^{134}$ and the Primary School Curriculum (1971). ${ }^{135}$ This gave explicit recognition to the denominational nature of schools and provided for an integration of religious and secular education, thus preventing pupils from opting out of religious instruction. Children occupied a subordinate position in society, their behaviour was strictly controlled, society emphasised passivity while schools embraced the liberal use of corporal punishment. ${ }^{136}$ Biographies from this era paint a dismal picture of school life in the opening decades of the Free State, highlighting the prevalence of authoritarian teacher-pupil relationships, physical violence and corporal punishment. ${ }^{137}$

From the late 1960s, all facets of Irish life and Irish society were changing dramatically. The child-centred curriculum introduced in 1971 captured much of this fervour for change nationally and distilled learning from international examples. The curriculum introduced placed an emphasis on the value of childhood as a distinct period of life as well as a preparation for future citizenship. Moreover, it placed the needs and interests of children, interacting with their environments, to the fore. The abolition of corporal punishment in $1982^{138}$ was aligned to the concept of child-centredness espoused in the New Curriculum and to the more enlightened conceptualisation of childhood prevalent in wider society. This child-centred ideology continued to inform the curriculum introduced in 1999 and the aims, vision and principles of the curriculum were expanded to incorporate new understandings of children, childhood and education in the interim. As the curriculum is reviewed into the future, no doubt there will be a gradual evolution in philosophy as understanding of pedagogy deepens and as the diverse needs of society grow.

While the philosophy and ideology underpinning the curriculum may not always have been articulated strongly at a practical level in all schools, they demonstrate the predominant values of the society which developed the curricula and which determined priorities for its children. No doubt, societal priorities and imperatives will continue to change into the future and demands will continue to be placed on schools to respond to those priorities. 


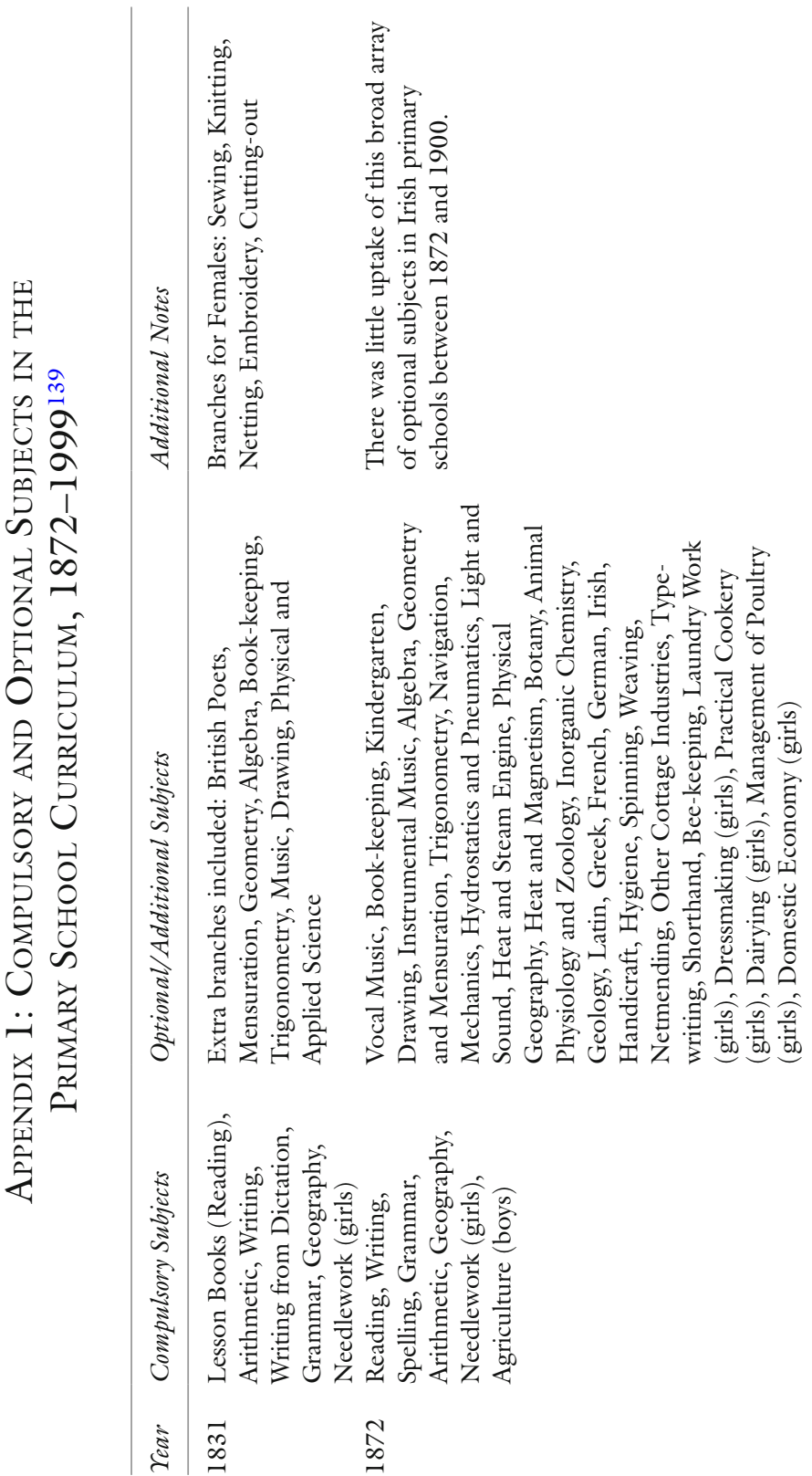




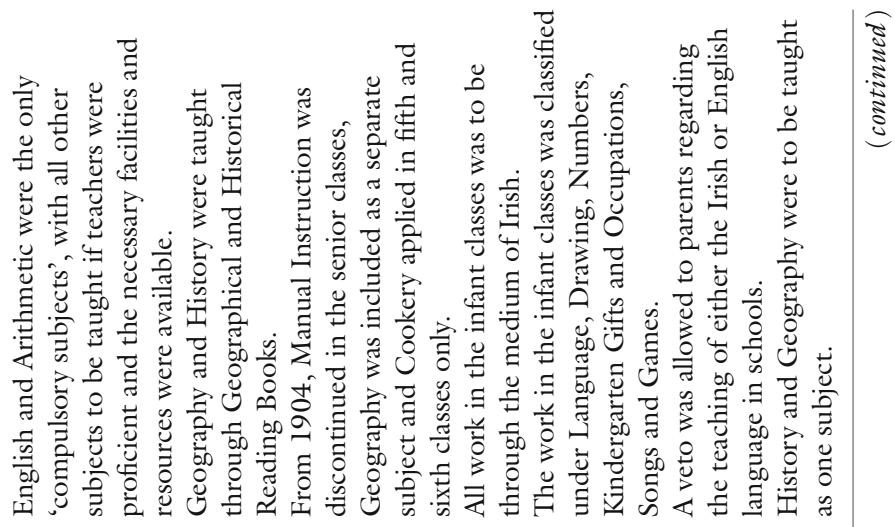

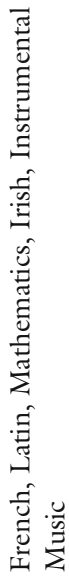
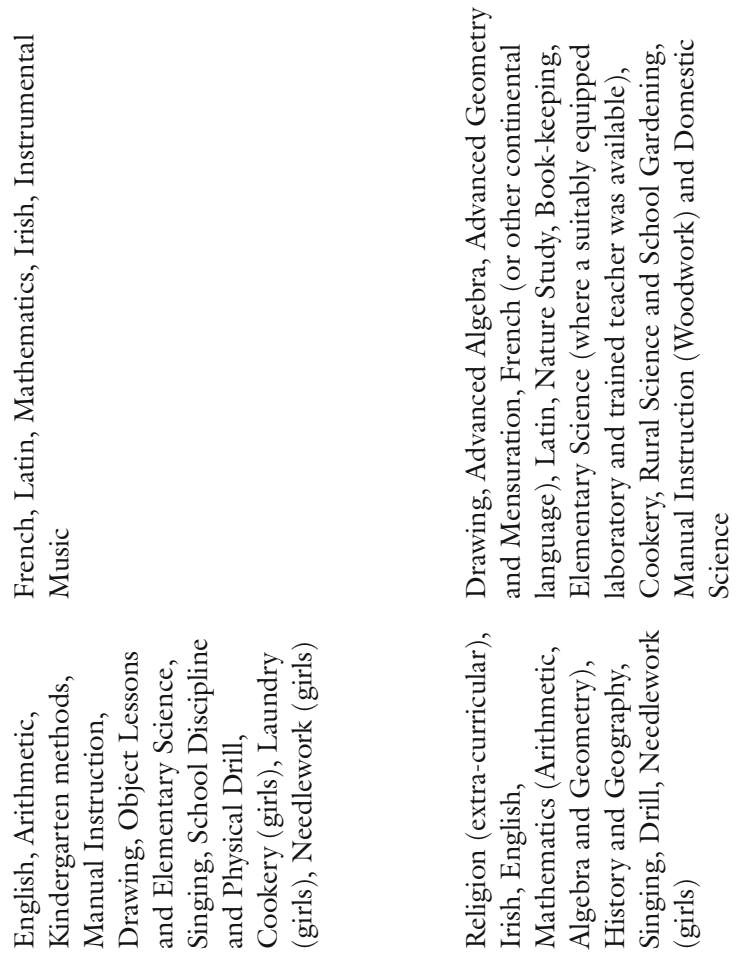

๖ำ

$\stackrel{\text { }}{2}$ 


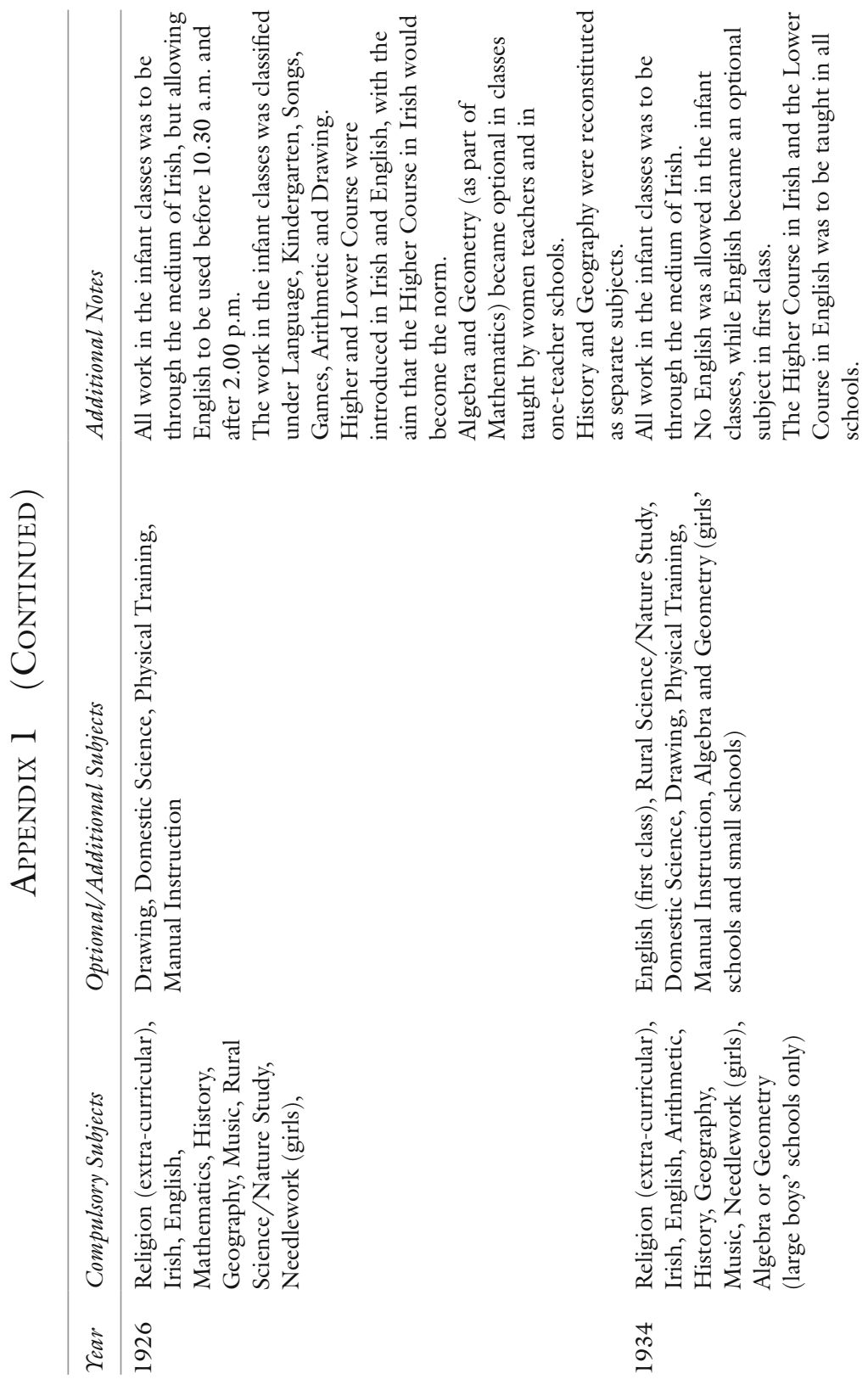



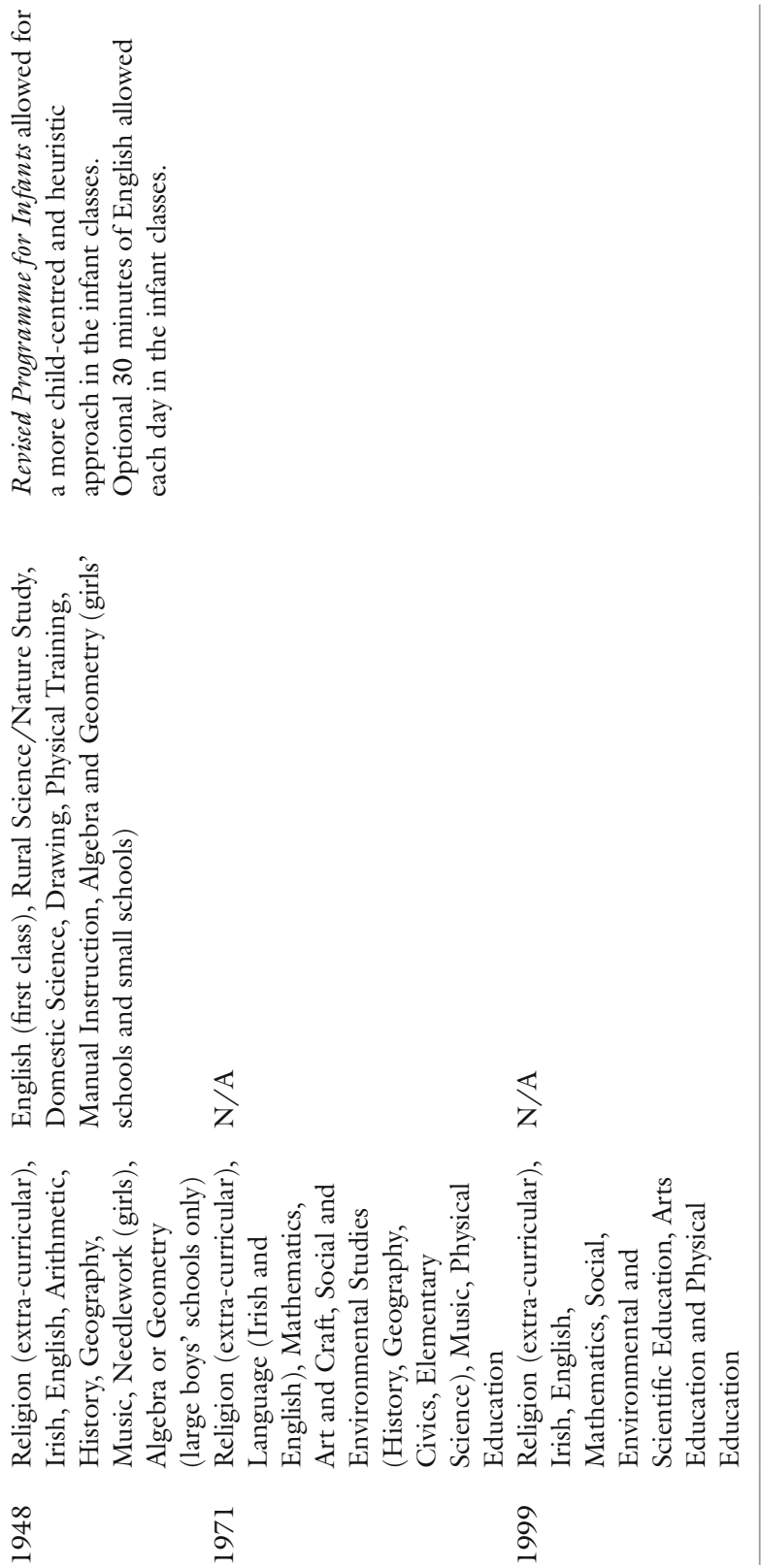


\section{Appendix 2. 12 Practical Rules for National Teachers $^{140}$}

Practical Rules for the Teachers of National Schools

1. The Teachers of National Schools are required-To keep at least one copy of the GENERAL LESSON suspended conspicuously in the School-room, and to inculcate the principles contained in it on the minds of their pupils.

2. To exclude from the School, except at the hours set apart for Religious Instruction, all Catechisms and Books inculcating peculiar religious opinions.

3. To avoid fairs, markets, and meetings - but above all, POLITICAL meetings of every kind; to abstain from controversy; and to do nothing either in or out of School which might have a tendency to confine it to any one denomination of Children.

4. To keep the Register, Report Book, and Class Rolls accurately, neatly, and according to the precise form prescribed by the Board; and to enter or mark in the two latter, before noon each day, the number of Children in actual attendance.

5. To classify the Children according to the National Schools Books; to study those Books themselves; and to teach according to the improved method, as pointed out in their several prefaces.

6. To observe themselves, and to impress upon the minds of their Pupils, the great rule of regularity and order-A TIME AND PLACE FOR EVERY THING, AND EVERYTHING IN ITS PROPER TIME AND PLACE.

7. To promote, both by precept and example, CLEANLINESS, NEATNESS, and DECENCY. To effect this, the Teachers should set an example of cleanliness and neatness in their own person, and in the state and general appearance of their Schools. They should also satisfy themselves, by personal inspection every morning, that the Children have had their hands and faces washed, their hair combed, and clothes cleaned, and, when necessary, mended. The school apartments, too, should be swept and dusted every evening, and whitewashed at least once a year.

8. To pay the strictest attention to the morals and general conduct of their Pupils and to omit no opportunity of inculcating the principles 
of TRUTH and HONESTY: the duties of respect to superiors and obedience to all persons placed in authority over them.

9. To evince a regard for the improvement and general welfare of their Pupils, to treat them with kindness, combined with firmness, and to aim at governing them by their affections and reason, rather than by harshness and severity.

10. To cultivate kindly and affectionate feelings among their Pupils; to discountenance quarrelling, cruelty to animals, and every approach to vice.

11. To record in the Report Book of the School the weekly receipts of School fees, and the amount of all grants made by the Board, as well as the purposes for which they were made, whether in any way of Premiums, Salaries to Teachers, payments to Monitors, or Workmisstresses, also School requisites, whether Free Stock or purchased at half-price.

12. To take strict care of the Free Stock of Books granted by the Board; and to endeavour to keep the School constantly supplied with National School Books and requisites for sale to the Children, at the reduced prices charged by the Commissioners; also to preserve the invoices for the information of the Inspectors; and whenever requisites (whether free stock or purchased) arrive without an invoice, to apply to the manager to whom it is transmitted when the parcel is sent from this office.

\section{Notes}

1. D. Akenson, The Irish Education Experiment: The National System of Education in the Nineteenth Century (London, 1970); J. Coolahan, Irish Education-History and Structure, (Dublin, 1981).

2. Hedge Schools were schools often held outside in out-of-the-way places to evade the laws forbidding Catholic education.

3. $9^{\text {th }}$ Report of the Commissioners of Irish Education Inquiry, 1827, Appendix $5,60-61$.

4. P. Dowling, The Hedge Schools of Ireland, (Dublin, 1935), 43.

5. J. Harford, 'The Emergence of a National Policy on Teacher Education in Ireland', Journal of Educational Administration and History, 2009, 41, 1, 45-56; K. Kitching, The Politics of Compulsive Education-Racism and Learner-Citizenship (London, 2014). 
6. G. O'Brien, 'The 1825-1826 Commissioners of Irish Education Reports: Background and Context' in G. Fitzgerald, Irish Primary Education in the Early Nineteenth Century: An Analysis of the First and Second Reports of the Commissioners of Irish Education Inquiry, 18251826, (Dublin, 2013), 5.

7. Ibid.

8. H. Hislop, 'The management of the Kildare Place Society System 18111831', Irish Educational Studies, 1992, 11, 52-71.

9. Reports from the Commissioners of the Board of Education in Ireland; Fourteenth Report: View of the Chief Foundations, with some General Remarks, and Results of Deliberations. H.C., 1809-12, 327-34.

10. Ist Report of the Commissioners of Irish Education Inquiry. H.C., 1825 (400), XII.

11. 58th Report of the Commissioners of National Education in Ireland for 1891, H.C. 1892, [C.-6788-1], Appendix B, Rules and Regulations of the Commissioners of National Education in Ireland, 2.

12. Reports of the Commissioners of National Education in Ireland from 1834 to 1845 inclusive, H.C. 1851, Volume 1, 3.

13. J. Coolahan, 'Imperialism and the Irish National School System' in J. Mangan, (Ed.), Benefits Bestowed? Education and English Imperialism. (Manchester, 1998), 77-93, 78.

14. J. Harford, 'The Emergence of a National Policy on Teacher Education in Ireland', Journal of Educational Administration and History, 2009, $41,1,45-56$.

15. The Church Education Society was established by the Established Church in 1839 to support Church of Ireland children in national schools under sole or joint Church of Ireland patronage by making grants available in various ways. The majority of the Church Education Society schools had returned to the national system by the end of the century following the disestablishment of the Church of Ireland in 1869.

16. 17th Report of the Commissioners of National Education in Ireland for 1850. H.C. 1851, [Cd. 1405], Appendix G, 480.

17. 68th Report of the Commissioners of National Education in Ireland for 1901, H.C. 1902, [Cd. 1198], 17-18.

18. The Recent Pastoral of the Catholic Hierarchy. Irish Teachers Journal, 6th October 1900, 4-5, 4.

19. 68th Report of the Commissioners of National Education in Ireland for 1901, H.C. 1902, [Cd. 1198], 13.

20. 66th Report of the Commissioners of National Education in Ireland for 1899-1900, H.C. 1900, [Cd. 287], Section II, Appendix M, 116.

21. T. Inglis, Moral Monopoly-The Rise and Fall of the Catholic Church in Modern Ireland, (Dublin, 1998), 122. 
22. M. Nic Ghiolla Phádraig, 'The Power of the Catholic Church in the Republic of Ireland' in P. Clancy, S. Drudy, K. Lynch, and L. O'Dowd, (Eds.), Irish Society-Sociological Perspectives, (Dublin, 1995), 593-619, 596.

23. B. Titley, Church, State and the Control of Schooling in Ireland 19001944, (Dublin, 1983), 161.

24. S. Ó Buachalla, Education Policy in Twentieth Century Ireland, (Dublin, 1988), 28.

25. P. Wall, 'The Catholic Hierarchy and Education, 1898-1908', Oideas, Autumn 1981, 24, 18-30, 25.

26. J. Mescal, Religion in the Irish System of Education, (Dublin, 1957), 143; N. Atkinson, Irish Education-A History of Educational Institutions, (Dublin, 1969), 194; J. Whyte, Church and State in Modern Ireland 1923-1979-Second Edition, (Dublin, 1990), 21.

27. Record of Irish Ecclesiastical Events for the Year 1921. Irish Catholic Directory, 20th October 1921, 577-8.

28. Department of Education, Report of the Department of Education for the School Years 1925-26-27 and the Financial and Administrative Year 1926-1927, (Dublin, 1928), 106; Department of Education, Tuarascáil 1965-1966 (The Stationery Office, Dublin, 1968), 23.

29. Department of Education, Report of the Department of Education for the School Year 1924-1925 and the Financial and Administrative Years 192425-26, (Dublin, 1926), 7.

30. D. Glendenning, Education and the Law, (Dublin, 1999), 52.

31. W. Abbott (Ed.), The Documents of Vatican II, (London, 1966).

32. L. O'Flaherty, 'Religious Control of Schooling in Ireland: Some Policy Issues in Review', Irish Educational Studies, Spring 1994, 13, 62-70; P. Clancy, 'Education Policy' in S. Quinn, P. Kennedy, A. O'Donnell and G. Kiely (Eds.), Contemporary Irish Social Policy, (Dublin, 1999), 72-107.

33. Department of Education, White Paper on Educational Development, (Dublin, 1980), 34.

34. S. Drudy and K. Lynch, Schools and Society in Ireland, (Dublin, 1993), 79.

35. J. Harris, 'The Policy-making Role of the Department of Education' in D. Mulcahy and D O'Sullivan (Eds.) Irish Educational Policy-Process and Substance (Dublin, 1989), 7-25.

36. J. Walshe, A New Partnership in Education-From Consultation to Legislation in the Nineties (Dublin, 1999).

37. D. Akenson, The Irish Education Experiment: The National System of Education in the Nineteenth Century (London, 1970), 50.

38. D. McCartney, 'From Parnell to Pearse 1891-1921' in T. Moody and T. Martin (Eds.) The Course of Irish History (Cork, 1967), 294-312. 
39. A. Doyle, A History of the Irish Language from the Norman Invasion to Independence (Oxford, 2015), 107.

40. T. Brown, Ireland: A Social and Cultural History 1922-1979 (Glasgow, 1981).

41. D. McCartney, 'Education and the Language, 1938-1951' in K. Nowlan and T. Williams (Eds.), Ireland in the War Years and After 1939-51 (Dublin, 1969), 80-94, 91.

42. J. Whyte, 'Ireland 1966-1982' in T. Moody and F. Martin (Eds.), The Course of Irish History (Cork, 1984), 342-362; S. Farren, The Politics of Irish Education 1920-1965 (Belfast, 1995), 225.

43. D. Ferriter, The Transformation of Ireland 1900-2000 (London, 2004).

44. A. Hyland, 'The Treasury and Irish Education 1850-1922: The Myth and the Reality', Irish Educational Studies, 1983, 3, 2, 57-82, 70.

45. J. Meenan, The Irish Economy since 1922, (Liverpool, 1970); J. Murphy, Ireland in the Twentieth Century, (Dublin, 1975).

46. D. Tussing, Irish Educational Expenditures-Past, Present and Future, (Dublin, 1978), 164.

47. Department of Finance, Economic Development, (Dublin, 1958).

48. Department of Education, Investment in Education-Report of the Survey Team appointed by the Minister for Education in October 1962, (Dublin, 1965 ).

49. D. O'Malley, 'University Education in Dublin-Statement of Minister for Education', 18th April 1967. Studies, Summer 1967, LVI, 222, 11321,115 .

50. T. O’Donoghue, Bilingual Education In Ireland 1904-1922-The Case of the Bilingual Programme of Instruction, (Perth, 2000).

51. M. Wall, 'The Decline of the Irish Language' in B. Ó Cuív (Ed.), A View of the Irish Language, (Dublin, 1969), 81-90, 82; A. Doyle, A History of the Irish Language from the Norman Invasion to Independence, (Oxford, 2015).

52. P. Ó Loinsigh, 'The Irish Language in the Nineteenth Century', Oideas, Spring 1975, 14, 5-21, 5.

53. The Society for the Preservation of the Irish Language was established in 1876 to encourage the use of the Irish language by establishing classes for its instruction and to promote a modern literature in Irish. The Gaelic Athletic Association was founded in 1884 to support the preservation and cultivation of native Irish pastimes, most notably hurling and football. The Gaelic League (Conradh na Gaeilge) was established in 1893 to revive the Irish language and to preserve Irish literature, music and traditional culture.

54. D. Akenson, A Mirror to Kathleen's Face-Education in Independent Ireland 1922-1960, (London, 1975), 39. 
55. Royal Commission of Inquiry into Primary Education (Ireland), H.C. 1870, [C.-6], Volume 1.

56. 37th Report of the Commissioners of National Education in Ireland for 1870, H.C. 1871, [C.360-I], 7.

57. J. Coolahan with P. O'Donovan, A History of Ireland's School Inspectorate 1831-2008, (Dublin, 2009), 19-21.

58. 37th Report of the Commissioners of National Education in Ireland for 1870, H.C. 1871, [C.360-I], Appendix A, 61.

59. B. Walsh, 'Asking the Right Questions; Teacher Education in the Republic of Ireland', Education Research and Perspectives, (UWA, 2006), 33, 2 , 37-59.

60. 2nd Report of the Commissioners of National Education in Ireland for $1835,18$.

61. Royal Commission of Inquiry into Primary Education (Ireland), H.C. 1870, [C.-6] Conclusions and Recommendations Contained in the General Report, Volume 1, Part V, 427.

62. W. Walsh, Statement of the Chief Grievances of Irish Catholics in the matter of Education, Primary, Intermediate and University, (Dublin, 1890), 99.

63. 14th Report of the Commissioners of National Education in Ireland for 1847. H.C. 1848, [981], Appendix XXVII, 132-133.

64. Royal Commission of Inquiry into Primary Education (Ireland), H.C. 1870, [C.-6] Conclusions and Recommendations Contained in the General Report, Volume 1, Part X, Recommendation No. 2, 522.

65. 68th Report of the Commissioners of National Education in Ireland for 1901, H.C. 1902, [Cd. 1198], 13.

66. A. Hyland and K. Milne, Irish Educational Documents-Volume 1. Selection of Extracts from Documents relating to the History of Irish Education from the Earliest Times to 1922, (Dublin, 1987), 128.

67. J. Coolahan, 'Education' in the Training Colleges-Carysfort 1877-1977: Two Centenary Lectures. (Dublin, 1981), 20-52, 23.

68. Commission on Manual and Practical Instruction in Primary Schools under the Board of National Education in Ireland, Final Report of the Commissioners, (Dublin, 1898), [C.-8923], 56.

69. Ibid.

70. A. Hyland, 'The Process of Curriculum Change in the Irish National School System', Irish Educational Studies, 1987, 6, 2, 17-38, 21.

71. For a summary see T. Walsh, Primary Education in Ireland 1897-1990: Curriculum and Context, (Bern, 2012), 59-84; A. Hyland, Educational Innovation-A Case Study. An Analysis of the Revised Programme of 1900 for National Schools in Ireland, (1973, M.Ed. Thesis, Dublin: Trinity College Dublin). 
72. F.H. Dale, Report of Mr. F.H. Dale, His Majesty's Inspector of Schools, Board of Education, on Primary Education in Ireland, [Cd. 1981], (Dublin, 1904).

73. See: T. Walsh, Primary Education in Ireland 1897-1990: Curriculum and Context, (Bern, 2012), 59-84.

74. 72nd Report of the Commissioners of National Education in Ireland for 1905-1906, H.C. 1906, [Cd. 3254], Appendix, Section II (K), 191-212.

75. 71st Report of the Commissioners of National Education in Ireland for 1904, H.C., 1905, [Cd. 2567], 28.

76. See T. O'Donoghue, Bilingual Education In Ireland 1904-1922-The Case of the Bilingual Programme of Instruction, (Perth, 2000).

77. 86th Report of the Commissioners of National Education in Ireland for 1919-1920, [Cmd. 1476], 9.

78. W.J.M. Starkie, Recent Reforms in Irish Education. An Address read before the British Association Belfast, 11th September 1902, (Dublin, $1902), 33$.

79. T. O'Doherty, 'William Starkie: The Teacher's Adversary', Irish Educational Studies, 1999, 18, 248-60; J. Coolahan, 'Education' in the Training Colleges-Carysfort 1877-1977: Two Centenary Lectures, (Dublin, 1981), 20-52, 31 .

80. 71st Report of the Commissioners of National Education in Ireland for 1904, H.C., 1905, [Cd. 2567], 1-2.

81. 86th Report of the Commissioners of National Education in Ireland for 1919-1920, [Cmd. 1476], 28.

82. National Programme Conference, National Programme of Primary Instruction, (Dublin, 1922).

83. National Programme Conference, Report and Programme presented by the National Programme Conference to the Minister for Education, (Dublin, 1926).

84. E. Keroudie, Nationalism, (London, 1961), 62-91, 67.

85. E. De Valera (1937) 'The Constitution of Ireland, Radio Broadcast 29th December 1938' in M. Moynihan, (Ed.), Speeches and Statements by Eamonn de Valera 1917-1973, (Dublin, 1980), 365.

86. See: T. Walsh, Primary Education in Ireland 1897-1990: Curriculum and Context, (Bern, 2012), 130.

87. D. Akenson, A Mirror to Kathleen's Face-Education in Independent Ireland 1922-1960, (London, 1975), 37.

88. Department of Education, Statistics relating to National Education in Saorstát for the Year 1922-1923, (Dublin, 1925), 6.

89. National Programme Conference, National Programme of Primary Instruction, (Dublin, 1922), 15. 
90. B. Ó Cuív, 'Education and Language' in D. Williams (Ed.), The Irish Struggle 1916-1926, (London, 1969), 153-66.

91. Circular 11/60; Teaching of Irish.

92. Department of Education, Revised Programme of Primary Instruction, (Dublin, 1934).

93. Department of Education, Revised Programme for Infants, (Dublin, 1948).

94. Department of Education, The Infant School-Notes for Teachers, (Dublin, 1951), 3 .

95. A. Kelly, Compulsory Irish: Language and Education in Ireland 1870s-1970s, (Dublin, 2002).

96. Circular 7/43; Circular to Managers and Principal Teachers of National Schools-Revised Regulations for the Primary School Certificate Examination.

97. See: T. Walsh, Primary Education in Ireland 1897-1990: Curriculum and Context, (Bern, 2012), 171-204.

98. Department of Education, Report of the Council of Education, (Dublin, 1954).

99. J. Coolahan, 'Education' in the Training Colleges-Carysfort 1877-1977: Two Centenary Lectures, (Dublin, 1981), 20-52.

100. Department of Education, Report of the Department of Education for the School Year 1924-1925 and the Financial and Administrative Years 192425-26, (Dublin, 1926), 41.

101. The pupil-teacher scheme operated for students who had passed the Intermediate Certificate (lower secondary education) with honours. They were selected in order of merit to attend upper secondary education, usually through the medium of Irish, where they practised teaching each week as part of their studies. Once they passed the Leaving Certificate and an oral examination in Irish, they were eligible for entry to the training colleges.

102. The Easter Examinations were held at Easter each year in a wide range of written and oral tasks to select students, in conjunction with their Leaving Certificate results, for entry to the training colleges.

103. Department of Education, Report of the Department of Education 19351936, (Dublin, 1937), 9.

104. Department of Education, Report of the Council of Education, (Dublin, 1954), para. 97.

105. An Roinn Oideachais, Tuarascáil-Táblai Staitistic 1968/19691971/1972, (Baile Átha Cliath, 1974), 17.

106. Department of Education, Report of the Department of Education 19281929, (Dublin, 1930), 21. Circular 12/31; Circular to Inspectors on the Award of Highly Efficient and Efficient Ratings, 2. 
107. Comhairle na Gaelige, Irish in Education, (Dublin, 1974), 17.

108. Central Statistics Office, Statistical Abstract of Ireland 1967, (Dublin, 1967), 55.

109. A. Loxley, A. Seery and J. Walsh, 'Investment in Education and the Tests of Time', Irish Educational Studies, 2014, 33, 2, 173-191.

110. Department of Education, Investment in Education-Report of the Survey Team appointed by the Minister for Education in October 1962, (Dublin, 1965 ).

111. P. McGee, 'Country Briefing: Special Education in Ireland', European Journal of Special Needs Education, 1990, 5, 1, 48-63.

112. S. Boldt, B. Devine, D. Mac Devitt and M. Morgan, Educational Disadvantage and Early School Leaving - Discussion Papers, (Dublin, 1998).

113. Gaelscoileanna are Irish-medium schools where the Irish language is the language of instruction. The Irish language is also the language of communication between the staff, pupils and school management.

114. A. Hyland, 'The Multi-denominational Experience in the National School System in Ireland', Irish Educational Studies, 1989, 8, 1, 89-114, 98.

115. Circular 20/71; New Curriculum-Pilot Schools.

116. Department of Education, Primary School Curriculum: Teacher's Handbook-Part 1, (Dublin, 1971), 12.

117. T. Ó Domhnalláin, 'Buntús Gaeilge-Cúlra, Cur le Chéile, Cur i Bhfeidhm' Teangeolas, 1981, 13, 24-32, 29.

118. C. Sugrue, Complexities of Teaching: Child-centred Perspectives, (London, 1997), 25.

119. See T. Walsh, Primary Education in Ireland 1897-1990: Curriculum and Context, (Bern, 2012), 283-342.

120. Organisation for Economic Cooperation and Development, Reviews of National Policies for Education-Ireland, (Paris, 1991), 67.

121. V. Greaney, A. Burke and J. McCann, J., 'Entrants to Primary Teacher Education in Ireland', European Journal of Teacher Education, 10, 2 (1987), 127-40, 127.

122. D. Tussing, Irish Educational Expenditures-Past, Present and Future, (Dublin, 1978); T. Kellaghan, 'The Interface of Research, Evaluation, and Policy in Irish Education' in D. Mulcahy and D. O'Sullivan (Eds.), Irish Educational Policy-Process and Substance, (Dublin, 1989), 191-218.

123. S. Ó Suilleabháin, 'Teachers' Centres: Theory and Practice', Oideas, Summer 1973, 10, 13-17, 13.

124. Department of Education, Report of the Primary Education Review Body, (Dublin, 1990). 
125. Review Body on the Primary Curriculum, Report of the Review Body on the Primary Curriculum, (Dublin, 1990).

126. Department of Education (1992) Education for a Changing WorldGreen Paper on Education, (Dublin, 1992).

127. J. Coolahan, 'Report of the National Education Convention', (Dublin, 1994).

128. Department of Education, Charting our Education Future-White Paper on Education, (Dublin, 1995).

129. Government of Ireland, Teaching Council Act, (Dublin, 2001).

130. Government of Ireland, Education Act, (Dublin, 1998).

131. Department of Education and Science, Primary School Curriculum, (Dublin, 1999).

132. T. Walsh, 'Constructions of Childhood in Ireland in the Twentieth Century-A View from the Primary School Curriculum 1900-1999', Childcare in Practice, 2005, 11, 2, 253-69.

133. R. Selleck, The New Education-The English Background 1870-1914, (Melbourne, 1968).

134. Department of Education, Rules for National Schools under the Department of Education, (Dublin, 1965), 8.

135. Department of Education, Primary School Curriculum: Teacher's Handbook-Part 1, (Dublin, 1971).

136. D. Devine, 'Children: Rights and Status in Education-A Socio-historical Analysis', Irish Educational Studies, Spring 1999, 18, 14-28.

137. D. Ferriter, 'Suffer Little Children? The Historical Validity of Memoirs of Irish Childhood' in J. Dunne and J. Kelly (Eds.), Childhood and its Discontents-The First Seamus Heaney Lectures, (Dublin, 2003), 69-106. See also: P. Crosbie, Your Dinner's Poured Out! (Dublin, 1981), 172-90, 179; P. Touher, Fear of the Collar: Artane Industrial School, (Dublin, 2007); S. McMahon and J. O'Donoghue (Eds.), Tales out of School, (Dublin, 1993).

138. Circular 9/82; The Abolition of Corporal Punishment in National Schools.

139. Adapted from T. Walsh, Primary Education in Ireland 1897-1990: Curriculum and Context, (Bern, 2012), 451-453.

140. 14th Report of the Commissioners of National Education in Ireland for 1847. H.C. 1848, [981], Appendix XXVII, 132-133. 